\section{THE DOUBLE FAILURE OF THE MASTER AND THE SLAVE HIGHLIGHTED IN SELECTED WORKS BY CHINUA ACHEBE AND AMMA DARKO}

\author{
Théophile Houndjo ${ }^{1}$
}
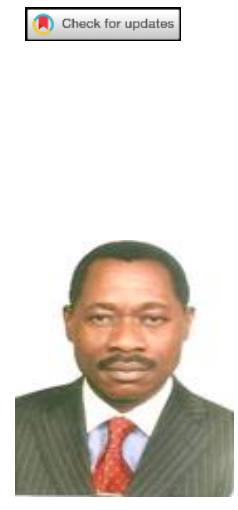

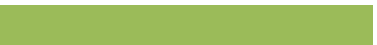

Article History

Received: 3 October 2018 Revised: 1 November 2018 Accepted: 27 November 2018 Published: 31 December 2018

\section{Keywords}

Failure

Coloniser

African

White man

Civilized

Gospel

Christian

God

Europe

Africa.

\author{
${ }^{\prime}$ Department of English (D.An.). Domain: English-speaking African \\ literature Faculty of Arts, Languages, Arts and Communications (FLLAC) \\ Laboratory of the Research Group on Africa and the Diaspora (GRAD) \\ University of Abomey-Calavi (Republic of Benin) \\ Email: thesympat@yahoo.fr
}

\title{
ABSTRACT
}

Colonization was sealed by the Berlin Conference in 1885 and represents the second main stage in the contact between Africa and Europe after slave trade. The aftermaths of colonization are still noticeable in Africa and will still be in the future. Although many documents, through ages, have dealt with what the relationships between Europe and Africa have usually been some African novelists have also dealt with either the colonization of their continent or its aftermath or both. Among them are Chinua Achebe and Amma Darko. This paper, based on Things Fall Apart and No Longer At Ease by Chinua Achebe, and on Beyond The Horizon by Amma Darko, aims at pointing out the failures of both the colonizer and the colonized. Marxism as a literary theory and the qualitative analysis approach have enabled me to realize that the two novels by Achebe and the one Amma Darko under study depict, in one way or the other, the socio-political and religious situations in most black (African) countries from precolonial to the post-independence periods. The study has reached the following conclusions. First both Europeans Africans are responsible for the underdevelopment situation Africa has experienced so far which is a failure. Then the Europeans' failure to prevent by all costs Africans from immigrating to their continent. Last Africans' failure to adopt adequate political and economic systems that can help develop their continent, compelling then their fellows to emigrate to Europe, where most of them end in despair and misery.

\section{INTRODUCTION}

While coming to Africa to colonize it, the white man actually brought with him some new ways of behaving and doing. These ways stemmed from such institutions as religion, economy and government. In his attempt to root and enforce these institutions in the black continent, the white man also brought with him a component of the European army. This army helped him to keep black people under his control. Apart from the army, the white man drew on two other components: missionaries and traders. Each of them had a specific role. The missionaries had to spread the Good News or Gospel. By spreading the Gospel among the African peoples, they pursued one main goal which was making them accept whatever happened to them. This enabled the white man to exploit and plunder pitilessly African resources. Then the army was used to discipline the Africans who tried to resist the white man's order. By so doing, the European invader dominated Africans on their own soil. Again, the traders helped the colonizer plunder African resources. Alluding to them, the narrator says that "the white man... had [...] built a 
trading store and for the first time palm-oil and kernel became things of great price, and much money flowed into Umuofia”, (Achebe, 1984).

This paper aims to explore the failures noticeable in the relationships between the colonizer and the colonized from the colonial period to date. To reach this goal, I have used Marxist theory and qualitative approach to conduct this study as said earlier. marxism has enabled me to grasp the real meaning of the clashes between Africans and the colonisers since colonial period. In the same way, the carelessness of the African political leaders towards their peoples in post-independence era on the one hand and the Europeans' contempt for African immigrants on the other hand can be understood through the use of the Marxist theory. The qualitative approach is suitable for this study since there is no numerical data to discuss. Apart from the introduction and the conclusions, the analysis proper of the findings is divided into two main parts. The first part is concerned with "Failures during colonisation" and the second one with "Failures after colonization"

\section{FAILURES DURING COLONISATION}

\subsection{The White Man's Failures in Africa during Colonization}

2.1.1. In the Religious Field

For Europeans who came to Africa to civilize it, Africa is a dark continent. This is to say, Africa is the continent of primitive people(s). In their view to bring light to Africa and Africans, they first brought missionaries, then soldiers and last traders. This is observed in Achebe's seminal novel Things Fall Apart. In this novel, the persona called the District Commissioner recounts the good that the white man has brought to Africans, especially to Umuofia people. He puts this in these terms:

We have brought a peaceful administration to your people so that you may be happy. If any man ill-treats you we shall come to your rescue. But we will not allow you to ill-treat others. We have a court of law where we judge cases and administer justice just as it is done in my own country under a queen (Achebe, 1984).

The District Commissioner says these words after Umuofia people have burnt the church established in their village following Eunoch's murdering of an egrongrwu. For the white colonizer embodied here in the District Commissioner, Africans do not know how to lead their own affairs nor administer justice, which is not totally true. In this sense, the narrator informs the reader that "he [the white colonizer] built a school and a little hospital in Umuofia." Achebe (1984) to prove this. A school is meant to train people and a hospital is meant to cure sick people. In order to match intention with action, some Africans are sent to school. Among them is Nwoye, Okonkwo's first son, almost as lazy as his grandfather Unoka. The narrator reveals here the news of Nwoye's being to the white man's school in the following terms:

It was in the first rainy season after Okonkwo's return to Umuofia that Mr Brown left for home. As soon as he had learnt of Okonkwo's return five months earlier, the missionary had immediately paid him a visit. He had just sent Okonkwo's son Nwoye, who was now called Isaac, to the new training college for teachers in Umuru (Achebe, 1984).

It should be noted that it is European missionaries who brought Christianity to Africa. It is the spiritual organization established by Jesus Christ or simply related to Him. The fundamental principle of Christianity is that Jesus Christ is the only son of God, sent to the world in order to save it because all the inhabitants of the earth have sinned. "No one can go to the father without me", said Jesus Christ himself. (The Revised Standard Version of the Holy Bible, John, 14:16). The missionaries spread the Gospel on the basis of the Ten Commandments. These commandments have been further summed up into two. The first commandment is "You shall love the Lord your God with all your heart, and with all your soul, and with your entire mind. And the second runs like this: "You shall 
love your neighbour as yourself." (The Holy Bible, Matthew 22:37) One verse of these two commandments goes as follows: "you shall not kill”. (The Holy Bible, Exodus 20:3)

In the New Testament, Jesus taught his disciples how to pray to God, the Father. He said:

..., for your Father knows what you need before you ask him. Pray then like this:

Our Father who art in heaven,

Hallowed be thy name,

Thy kingdom come,

Thy will be done,

On earth as it is in heaven.

Give us this day our daily bread;

And forgive us our debts,

As we also have forgiven our debtors,

And lead us not into temptation,

But deliver us from evil.

For if you forgive men their trespasses,

Your heavenly Father also will forgive you; but if you do not forgive men their trespasses,

Neither will your father forgive your trespasses," (The Holy Bible, Matthew 6:9-15).

The law or Good News or Gospel is clear: human beings should forgive one another and no one should kill his or her fellow. It can be noticed that, from the very beginning, the white people in general and the missionaries in particular, who have spread this teaching, have started breaking their own religious regulations. This is noted in the novel under study. The first illustration from this novel is what happens in Abame. As a matter of fact, when the white man has come to Abame, its people have never seen such a person before. So, they have tied his bicycle (that they call an iron horse) and killed him. The narrator relates this sad situation better: "And so they killed the white man and tied his iron horse to their sacred tree because it looked as if it would run away to call the man's friends" (Achebe, 1984). The main reason why Abame people have killed the white man is that they think he might "break their clan and spread destruction among them" (Achebe, 1984). For them, the white man is a strong and dangerous person that must be treated as such. Later on, events prove that they are right to suspect that the white man could destabilize their social organization or order. In this perspective, Obierika notes that: "The white man has put a knife on the things that held us together and we have fallen apart" (Achebe, 1984).

In reaction to the murder of their fellow, other white men fail to do what is expected from them: to seize the opportunity to show that a sinner must be forgiven. The sinner here is all Abame people. They need to prove to the 'savage black people' that they are really tolerant and forgiving. "Actions speak louder than words", says a popular proverb. The civilized white people who have claimed to be endowed with the right to civilize the 'uncivilized' black man have shown that they are not better. Because of their lack of pedagogy and tolerance, they destroy Abame marketplace, killing many people. The narrator narrates this heart-rending situation in these terms:

The iron horse was still tied up to the sacred silk - cotton tree. And then one morning three white men led by a band of ordinary men like us came to the clan ... The three white men and a very large number of other men surrounded the market. They must have used a powerful medicine to shoot. Everybody was killed, except the old and the sick who were at home and a handful of men and women whose chi were wide awake (Achebe, 1984).

In the above text, it is clearly specified that "everybody was killed". Because a white man has been killed, his fellow white people, the auto-proclaimed civilized people, helped by some Africans, have killed many Africans. This is a case of the white man's failure. The white men could have behaved otherwise! This is to say, they could have 
used this opportunity to prove what their religion teaches. It seems that they have misinterpreted the Gospel. The new converts obviously seem to have misinterpreted the Gospel too.

During the colonial period, some Africans misunderstood the Gospel. Others mixed their African traditional faith or sociological realities with the Gospel. Achebe represents this reality in his novels under scrutiny. He portrays some African Christians who refuse to accommodate their fellows because of class differences. Such is the case of the osus and the lepers whom the white man's religion considers as Christians because they attend celebrations and prayers but their African fellows think otherwise. But Mr Kiaga, a black character in Things Fall Apart, highly condemns this behaviour. He tells them that they are all equal before God. Therefore, they need to accept one another as brethren in Christ. While they obviously agree to tolerate these outcasts, they are actually not convinced in heart that this is godly or Christian. In fact, they have shown in many occasions that they are not only different from the outcasts but also superior to them. It is in this vein that Isaac Okonkwo and his wife Hannah, both Obi's parents, object to his marriage with Clara:

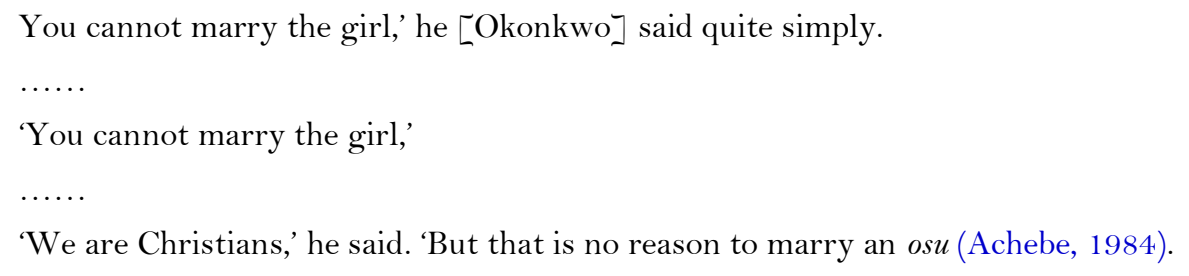

Here, there is a paradox and irony at two levels. The first one is the fact that Isaac Okonkwo, one of the first converts in Umuofia, is supposed to know that all human beings are equal before God. The second level of irony is that he is a fervent catechist, so he is twice supposed to know or remember this wise and right teaching from $\mathrm{Mr}$ Kiaga, the interpreter of the first missionaries in Umuofia, namely Mr Brown and James Smith. He tells the new converts who do not bear the presence of outcasts that "Before God, ... there is no slave or free. We are all children of God and we must receive these our brothers"” (Achebe, 1984)

Obi's mother is more menacing than his father. She tells her son in reaction to his informing her of his engagement with Clara:

I have nothing to tell you in this matter except one thing. If you want to marry this girl, you must wait until I am no more. If God hears my prayers, you will not wait long ...

'But if you do this thing while I am alive, you will have my blood on your head, because I shall kill myself.' She sank down completely exhausted (Achebe, 1984).

These words from Obi's parents prove that they have not understood or internalized the Gospel. Worse still, Obi's father acknowledges that Clara's father has become a Christian. This is an additional reason for Isaac Okonkwo to understand and accept or bear that their children can marry each other, but unfortunately he objects to this project or engagement. He says: "I know Josiah Okeke [Clara’s father] very well' ...' I know him and I know his wife. He is a good man and a great Christian. But he is osu." (Achebe, 1984). All the conditions are fulfilled so that Isaac and Hannah Okonkwo understand their son's situation but they do not, unfortunately. This is the white missionary's failure. He has not succeeded in putting in his converts the necessary light that can enable them to accept their brethren, the osus and lepers.

\subsubsection{Corrupt Colonial Justice and Africans' Laziness as the white man's failure}

First of all, the whole administration process of justice is awkward, and this enables irresponsible people to siphon justiciables' meagre resources. It is in this perspective that the court messengers have increased the fine that must be paid by the people of Umuofia in order to have Okonkwo and the other five elders freed from prison. Indeed, instead of the two hundred bags of cowries claimed by the District Commissioner, the court messengers, 
they are all Africans, have told the people of Umuofia that it is two hundred and fifty bags in order to keep the additional fifty bags for themselves. The narrator reveals that "they [the men of Umuofia] did not know that fifty bags would go to the court messengers, who had increased the fine for that purpose." (Achebe, 1984). This practice or way of behaving of the court messengers is not less than corruption. In addition to this instance of corruption, there are others. One of these is the one the court messengers and interpreters are accused of. The narrator says that "the white man's court has decided that it should belong to Nnama's family, who had given much money to the white man's messengers and interpreters."' (Achebe, 1984).

The second instance of failure of the white man in the process of justice administration is the flaws noticed in the care that the prisoners must enjoy. As a matter of fact, some prisoners are ill-treated in colonial time. This is the case of Okonkwo and his five unfortunate companions. The narrator reveals this in what follows:

As soon as the District Commissioner left, the head messenger, who was also the prisoners' barber, took down his razor and shaved off all the hair on the men's head. They were still handcuffed, and they just sat and moped ...

The six men ate nothing throughout that day and the next. They were not even given any water to drink, and they could not go out to urinate or go into the bush when they were pressed. At night the messengers came in to taunt and to knock their shaven heads together (Achebe, 1984).

The six elders of Umuofia are not treated fairly, which is against the prescriptions of civilized people. They have been frustrated although the District Commissioner "told the court messengers ... to treat the men with respect because they were the leaders of Umuofia." Achebe (1984) contrary to the prescriptions of The Holy Bible, the white colonizer has applied here the principle of "an eye for an eye, a tooth for a tooth" towards Africans. Others such as those who have molested the Christians or those who have thrown away their twins "were beaten in the prison by the kotman and made to work every morning clearing the government compound and fetching wood for the white commissioner and the court messengers" (Achebe, 1984).

The last instance of the white man's failure during the colonial era is the fact that the system favours laziness. Indeed, pre-colonial Africans are known to be hard workers and people of goodwill even though there have been some exceptions like Unoka. Colonization has made many Africans lazy. Such is the case of civil servants who are regularly absent from their office. As Mr Green notes, "the African is corrupt through and through" (Achebe, 1984). But Mr Green himself is a hard worker: "as a rule his [Mr Green's $]$ work took up so much of his time that he rarely played" (Achebe, 1984). Armah has also described the case of some African lazy people like "a man who had gone on leave in the countryside and then extended his free time by sending a long series of telegrams claiming the death of one after the other of a whole clan of relatives"(Armah, 1988).

\subsection{The Black Man's Weaknesses in Colonial Africa and after}

One of the failures of the African is the division of the different tribes and the domination of the white man's religion over African ones by the white colonizer and this certainly enables the latter to become strong or stronger to rule them. Resignedly, Obierika says:

The white man is very clever. He came quietly and peaceably with his religion. We were amused at his foolishness and allowed him to stay. Now he has won our brothers and our clan no longer act like one. He has put a knife on the things that held us together and we have fallen apart' (Achebe, 1984).

The failure of the black man is a success or victory for the white colonizer who does not need a better opportunity to dominate the black continent and its sons and daughters. I have already dealt with the corruption of the court messengers and court interpreters in the beginning of the colonial period. Indeed, in No Longer At Ease, Obi is welcomed in his native Nigeria from London by a corrupt customs agent who wants to take from him two 
pounds without any receipt instead of the required five (Achebe, 1984). The last but not the least instance of corruption is the behaviour of some civil servants on the day of Obi's trial. As a matter of fact, "some civil servants paid as much as ten shillings and six pence to obtain a doctor's certificate of illness for the day" in order to attend Obi’s trial (Achebe, 1980).

As a whole, during colonization, the white man has failed to observe his own principles. The black man, on his own soil, has been dominated and proved not to be able to observe some religious prescriptions. He also shows his involvement in corruption, which is a failure.

\section{Failures after Colonization}

\subsection{The Black Man's Failure \\ 3.1.1. In the Social and Political Fields}

When leaving Africa, the white man left behind him the political organization in his country, which is democracy. Democracy is, in short, the government of the people by the people and for the people. Democracy appeals to the establishment of some institutions called democratic institutions. Their number and designations vary from one country to another. There are often a government, a parliament and justice. In the normal course of things, the last two are independent from the Government. How has the black man coped with his country's political institutions after colonization?

After independence, the black people who have taken over from the white man have failed in the running of public affairs. This is illustrated by the military coup d'état and military rule that took place in African countries. This is described in some novels such as A Man of The People by Chinua Achebe, Money Galore by Amu Djoleto and The Beautyful Ones Are Not Yet Born by Ayi Kwei Armah. The fact that several or many military coups took place illustrates the failure of civilian rule in Africa. First, many African civilian leaders have not been able to satisfy the needs of their peoples. Second, some are dictators who deprive their citizens of freedom of speech, association and meeting to name only these.

People who lack the minimum, the strict minimum to live on in The Beautyful Ones Are Not Yet Born are people like the old woman who comes to Oyo at night to borrow some sugar, which she can't obtain, unfortunately. The narrator reports the old woman's world here: "Here I am again. Sugar. Would you be pleased to lend me a little sugar? Just for the children"” (Armah, 1988). Apart from that old woman, some other people who have experienced suffering and misery in the novel are Agya Akon, Tricky Mensah and Anan, the last but one lives in a converted lavatory. The narrator relates this better:

The crewman lived very close to the fishing harbor, in a room at the extreme end of a long, low house. It was already quite dark in his room, so that when he was called he came out squinting against the weak dusk light, muttering something loud and involved, something which seemed to mean that he was sorry he had no place to take the visitors to, that his room was not a room at all, only a converted lavatory. (Armah, Ibid, 150; emphasis mine)

In the political and social fields in post-independence era, the black man has failed.

\subsubsection{Predominance of the White Man's Religion over the African Ones}

The white man's religion has been rooted and more widespread in Africa than African ones. This supremacy has started since the very beginning of Christianity in Africa. As a proof, when the first Christians in Umuofia are given the sacred forest to build their church with the view of seeing them die one by one until the rest of them leave the place, none of them dies. This has encouraged several people to convert into Christianity (Achebe, 1984). Since the beginning, as it can be seen in Things Fall Apart, some African people have adopted the white man's religion but others, no. The narrator confirms in the following terms how the Christian community has grown very quickly: 
"The Christians had grown in number and werenow a small community of men., women and children, selfassured and confident. Mr Kiaga, the white missionary, paid regular visits to them 'When I think that it is only eighteen months since the Seed was first sown among you,' he said, 'I marved at what the Lord hath wrought”' (Achebe, 1984).

Christianity is noticeable and is the dominant religion in almost all the Anglophone West African countries. In A Man Of The People and A Grain Of Wheat by Ngugi wa Thiong'o, the reader can notice children wearing the dressings of some adepts of a traditional religion, singing Christian songs. By reading Anthills of The Savannah, one can notice the pacific cohabitation between Islam and a Christian religion during the naming ceremony of Elewa and Ikem's daughter, Amaechina. The event described as "ecumenical fraternization was neatly terminated with a lusty 'Hooray!' and laughter” (Achebe, 1988).

\subsubsection{The 'Crippled' Post-independence African Economy and Corruption}

Before colonization, African societies used to practise traditional economy whose features are mainly free access to ownership of production and solidarity among the populations in general and producers in particular. The main activities were gardening, hunting and subsistence farming. As far as exchange or trade was concerned, it was based on barter and there was no division of labour. Moreover, traditional values and customs were the norms. Although it was not perfect and the means of production and the goods were not sophisticated, this kind of society was peaceful. With the arrival of the white man, things started changing and have changed so far, negatively, of course, and unfortunately.

One of the new things that the white man has introduced is a modern way of doing trade. Money entered the system of transactions. Barter has become obsolete and proved to be too slow. Describing this new deal in Things Fall Apart, the narrator says that "the white man had indeed brought a lunatic religion, but he had also built a trading store and for the first time palm oil and kernel became things of great price, and much money flowed into Umuofia" (Achebe, 1984). From this moment till now barter is almost completely extinguished; so is African solidarity. Individualism and corruption have become the order of the day. As a consequence of all these, some people, the majority, are not and cannot be taken care of by governmental organizations and services. Poverty and misery prevail. There is collusion between business and politics.

One of the characteristics of African economy after independences is the ill-governance. An aspect of this illgovernance is embezzlement. Indeed, money is regularly embezzled in the public administration and this negatively affects the economy. Joseph Koomson, a Minister, declares that "after all, the Commercial Bank is ours, and we can do anything" (Armah, 1988), Corruption is also rooted in post-independence African societies.

Corruption that started in the beginning of colonization has been sophisticated and widespread as it is the result of the introduction of money, individualism and both yield the lust for material achievement. In Beyond The Horizon, Akobi has corrupted a man before obtaining his passport to move to Europe (Darko, 1995). Mara too has given money before getting her passport. She says that "one clerk there wanted to sleep with me before he pushed through my passport form, even before it got to the stage where I knew I would have to pay the bribes.” (Darko, Ibid: 52) Mara's agent who has brought her to Europe has also given a bribe at the immigration office because his vaccination card has expired. Mara lets the reader know that "the desk clerk tried to make a small palaver over some vaccination date of my agent's had long expired, but was expertly tackled with a five-pound note which my agent smartly pushed into the clerk's palm.” (Darko, Ibid: 56).

Corruption and bribery have become such a common practice that citizens are aware of the fact that when dealing with the civil service, the public administration, they must give a bribe at a certain moment be it sex, money or material goods. Here too the amount varies according to what you need or want. Mara confesses that "in the end, 
when I calculated, the bribes I had paid could have fed my whole family in the village for maybe a year or so." (Darko, Ibid: 52-53)

\subsubsection{Administration}

The white man has set up in Africa an administration. The narrator informs the reader that "apart from the church, the white men had also brought a government. They had built a court where the District Commissioner judged cases in ignorance" (Achebe, 1984). The District Commissioner confirms this when talking to the people of Umuofia. He says:

We have brought a peaceful administration to you and your people so that you may be happy. If any man ill- treats you we shall come to your rescue. But we will not allow you to ill-treat others. We have a court of law where we judge cases and administer justice just as it is done in my own country under a great queen." (Achebe, op. cit: 137)

Almost all complete administrative branches have been set up before independence. After the departure of the white man, black people apply the rules as 'they want'. Unqualified people are put where they should be. From the independence up to date, one of the difficulties citizens face in the public administration is the fact that the right person is not always put at the right place. People who are not qualified are appointed at top executive positions. Sometimes people are qualified but are appointed where they do not fit in. This state of affairs is an important cause of ill-governance of all sorts. In A Man Of The People, Chief Nanga is ironized as "the uncultured Minister of Culture". In the same novel, a lady, almost illiterate, is appointed at a high position because she is a member of the People's Organisation Party (POP), the Minister's party and becomes "an influential party woman." Her name is Mrs Eleanor John. The narrator says this about her:

I knew of her from the newspapers; she was a member of the Library Commission, one of statutory boards within the Minister's portfolio. Her massive coral beads were worth hundreds of pounds according to the whisper circulating in the room while she talked. She was the 'merchant princess' par excellence. Poor beginning - an orphan, I believe - no school education, plenty of good looks and an iron determination, both of which she put to good account; beginning as a street hawker, rising to small trader, and then to big one. At present, they said, she presided over the entire trade in imported second-hand clothing worth hundreds of thousands (Achebe, 1975).

\subsection{The White Man's Failure after African Countries' Independences}

Through the information the reader gets from the novels under study and the ones quoted in this article on the one hand and the real observable concrete running of African countries on the other, one can deduce, after a stock taking of politics, economy and society, that the white man has failed. There are more negative aspects than positive ones. Although African leaders are mainly responsible for that, the white man must also account for it, at least partly.

\subsubsection{The Failure in the Implementation of the White Man's Immigration Law}

\subsubsection{The Flaws at the Immigration Offices}

During colonization and a few years after independences, African people could more or less easily go to Europe. After independences this state of affairs lasted about three more decades. After the first two decades of independence, Western countries started hardening the conditions of entry into their countries. This is illustrated by the conditions to fulfill before getting visas in African countries for Europe; then the control systems during the flight including the transit in some countries before reaching destination; next the control once the immigrant 
reaches destination; and last the conditions to fulfill before getting the visa to stay in Europe. All these aspects have been dealt with in Amma Darko's Beyond the Horizon.

The first illustration of the white man's failure in the implementation of his selfish law restricting and even almost forbidding immigration into his country, for Africans mainly, is the fact that Akobi has successfully been "smuggled" to West Germany. The verb "to smuggle" is used to prove that he has reached there in an irregular way. It is difficult for them to move to Europe but someone like Akobi who does not even have a visa, gets to Europe. It is more than a failure for the white man who does not want to welcome some categories of Africans on his soil. About the difficulties Akobi has met in his attempts to have his papers to go to Europe, the narrator says:

Akobi had got his passport after heavily bribing someone at the passport office. He had deposited money for his ticket and even bought a brand new portmanteau, a couple of new shirts, trousers, ties and shoes. But still he had no entry visa for any European country. Then came a man somewhere along the line who claimed to have connections at embassies and said he could push through Akobi’s visa. He took a large sum of money which he said he could need to bribe his connections; then he disappeared, just as he had materialised, without a trace (Darko, 1995).

The white man's failure is clearly displayed in the above quotation. Akobi is not entitled to any visa and cannot get any and therefore has not got any. With regard to papers, he must stay in Africa. Surprisingly, someone volunteers to help him get it, through his connections at embassies. That person has disappeared after collecting the money from Akobi. At first sight, people can say that this person is just a thief or a gangster because he has not brought the visa he has promised. His goal is elsewhere: to rob Akobi of his money. But in actual fact, within embassies in African countries, there are really people who are involved in the establishment of genuine visas through fraudulent ways. Among these people are white employees working in these embassies for their countries. This is a failure for the white man who has decided to prevent Africans, at least a category of them, from entering Europe. It is an irony used by Amma Darko to have her readers laugh at the auto-proclaimed civilized white man.

Though the reader does not follow the different steps of Akobi flying from his native African country, Ghana, to Germany, the narrator just recalls how he has disappeared from his house without even saying a word to his wife. After that we see him in Europe two years after his flight there asking his wife, through a letter, to join him. Nevertheless, some details are given about the different steps of Mara's preparation until she reaches Akobi's apartment in Western Germany. The first step is how she has got her passport. Mara has encountered almost the same difficulties as her husband before getting her passport. She has had to bribe people and also used middle people too. It is what Mara tries to inform the reader about. Now that her passport is ready, she must start her preparations to go and join Akobi feverishly.

Mara gets ready to travel to West Germany. From her native African country to West Germany, she witnesses some sorts of bribery. Here too, the reader notices some limits or shortcomings of the measures the white man has taken to prevent most Africans from coming to Europe. This is a failure for the white man. In Mara's country the emigration offices host corruption and bribery. She says:

We passed through emigration without trouble. The desk clerk tried to make a small palaver over some vaccination date of my agent's which had long expired, but was expertly tackled with a five-pound note which my agent smartly pushed into the clerk's palm. I saw how the clerk's face lit up and shone when he noticed that the note was no local currency but hard Western currency which, when change on the black market, would feed him and his family for God knows how long. My agent knew his way about in these things. He travelled regularly between Africa and Europe. Men paid him to smuggle their wives and girlfriend, who had no valid visas, into Europe, a very risky but lucrative business that had rewarded him with a beautiful family house by the seaside in the city's coastal area, four food transport trucks and all the much-worshipped trapping of life à la civilization: television, radio, fridge - you name it...he had it all. He 
enjoyed this his jet-set life very greatly since, after all, all his -to-and-fro tickets were paid for by his customers. Akobi, for instance, had paid him his return trip to Europe, plus of course the cost of his labour (Darko, Ibid: 56-57).

Here too, the white man's failure is evidenced by the fact that even at emigration offices, people who must be prevented from travelling to Europe are let go. Mara's agent has an invalid card of vaccination and should be stopped to go forward but fortunately for him, he goes through the net of control and continues the way to Europe. After this step, Mara and her agent board a plane. At this level no control before boarding the plane. This is done; Mara reaches Europe precisely the Schönefeld airport in East Berlin, Germany. How has she happened to reach there?

Leaving Africa for Europe for an African demands that he or she has some papers such as a passport, a vaccination card, a ticket, a transit visa and a visa to stay for a period more or less long, to name only a few. Nevertheless she has succeeded in boarding a plane and even reached East Germany. Her transit visa has been obtained through bribery since she has never been to East German embassy in her native country. She confesses such a situation here: "immigration posed no problem at all here and I realized that it was because I had a transit visa even though I have never been to East German embassy at home. But like I said, my agent knew his job well.” (Darko, Ibid: 58). No matter the measures, black people find their way to cheat the white man to enter Europe.

Although solid measures are taken by the white man to control the establishment of visas, some people always succeed in having them mainly in a fraudulent way. This is Mara's case here. She clearly says that she has a transit visa even though she has "never been to the East German embassy". It clearly means that corruption and bribery prevail in Western embassies in general and East German's in particular. Both white employees and black ones are corrupt, neglecting the principles or conditions to fulfill before having a visa. What counts for them (these white and black officials and/or employees) is their bribe. In this channel of corruption, there are undoubtedly white employees and officials in the embassies and certainly in the host countries too. There are corruption and bribery at European airports too. This confirms what the Vice-President of Umuofia Progressive Union (UPU) has said about white people's involvement in corruption. He says: "You think white men don't eat bribe? Come to our department. They eat more than black men nowadays"' (Achebe, 1980).

\subsubsection{The Flaws in Transit Countries: East Germany for Instance}

At the Schönefeld Airport in East Berlin, some travellers from Africa “pay somewhere” (Darko, 1995). It is not specified that those who are paying some money to some East German official are given receipts. Mara's agent informs her that the travellers who are paying are those who do not have "West German visas but who got themselves cheap and bad agents". They are said to be bad because they do not succeed in convincing the white officials at immigration to take little money to allow those who do not have visas to go forward.

This is understandable because having taken little money, they do not have enough to pay heavy bribes to immigration officials. Both in Africa and in Europe, some employees at emigration and immigration whether they are black or white are corrupt and therefore do not play well their roles. This is a failure for the Western governments and officials whose goal is "to filter out (scree)" those coming to Europe. And this implies that the white people are not as faithful to their governments as some people usually think and/or say it .

The travellers who pay money to end up in refugee camps will 'ask for political asylum” (Darko, 1995). This too is an arrangement between the travellers and their agents, on the one hand and the white officials and the agents on the other. Mara has a transit visa and that is the reason why she has been able to leave East Germany for the West. In order to be able to stay in West Germany, she must have a resident card or staying permit for Germany, which she does not. How is she going to move to West Germany without this precious paper (resident visa/card or the staying permit) which is her second necessary passport from East Germany to the West? 


\subsubsection{Some White People's Disagreement with their Countries' Immigration Laws}

Through an arrangement, Mara moves to West Germany. An anonymous person, an African man, who reveals himself later on to be Osey, brings the passport of another African woman who looks like Mara. It is given to her to be used in order to reach West Germany freely. This is possible because Germans see Africans as people who "look the same" (Darko, 1995). The narrator reports this situation here:

In the German people's eyes,' the anonymous third began, 'we nigger all look the same. Black face, kinky hair, thick lips. We don't fight with them above it. We use it to our benefit. He laughed cynically.

“But I still don’t understand why I must use this passport; I complained

'Because this woman whose passport you have has a valid staying permit for West Germany for at least five years, thanks to some poor wretched and destroyed German drug addict she married. And using it from here to West Berlin is like you came from West Berlin to look around East Berlin and you are returning back to West Berlin (Darko, 1995)

The white man who thinks that he is civilized, clever, intelligent, dynamic and omniscient is being cheated by his 'slave' or 'savage' or the former uncultivated and uncultured people, the Africans. This is his failure. Through this tricky way, Mara reaches her destination, West Germany. She confirms the failure of the white man which corresponds to the black man's victory to go to the almost forbidden land to him but which he considers, in his head, as the promised land, Europe: “No wonder my agent and his friend were so damned confident I wouldn’t get caught. They were too well-versed in the German mentality. So that just as smoothly as I was promised, I entered the West without needing to proclaim myself a political refugee” (Darko, 1995). She speaks as if entering West Germany is already being or entering the Heaven, the Paradise or at least booking a room there.

\subsubsection{White Officials' Carelessness about the Application of their Countries' Villain laws}

Mara is now in West Germany, the country where her husband Akobi has already been for two years. This has been possible although she has not had her own papers. The white man's carelessness for black people at checking points sometimes provides the latter with some benefits. Here, it has favoured this (situation) because it is another woman's passport she has finally. This is what Osey refers to when he has said: "We don't fight with them above it. We use it to our benefit". Other people have enjoyed the flaws of the same process to enter Europe or German before Mara.

Before Mara, Akobi has gone through the same process. It is said that he has been "smuggled to Germany". Apart from Akobi, there is Comfort, Akobi's cherished and beloved mistress. She has been to West Germany for more than a year before Mara. Before Comfort, Kaye has moved to West Germany from Africa. She is relatively well-off since she runs a famous sex club called Peepy owned by her former sex customer and currently husband, Pompey, a "disciplined businessman in his field, that is, who never went back on his contracts” (Darko, 1995).

Akobi Ajaman or Cobby, Mara his wife, Comfort, Kaye, to name just a few, have been able to leave Africa to stay in West Germany through illegal ways despite all the measures taken by the white man at the level of both emigration and immigration offices. This is a failure for the clever, 'civilized' and omniscient white man in the implementation of his laws and regulations about the entry in his country. The failure is so flagrant and humiliating that white people are also involved in the process, the malpractice which enables those who are supposed to be prevented from going and staying in Europe to come and stay there. Once in Europe, how do these black citizens happen to stay there for months and years?

The white man has taken measures against both entering Europe and staying there. In this framework, the situation is more difficult for illegal residents than anybody else. Nevertheless, they try to cope with the situation but also find their ways out somehow. The next point is the situation of a few instances of the Africans who have illegally moved to Europe in general and West Germany in particular. 


\subsubsection{The Lots of Illegal Male Africans in Europe}

When Akobi has reached West Germany, it has been difficult for him to live the life of a human being. The reason for such a situation is known. He has had nowhere to stay. He has finally stayed with Osey for a while. The life of human being is not just to stay somewhere. A human being of a certain age, an adult above all, must work to provide for the fundamental or basic needs namely housing, food, health, education and clothing. Since it is already difficult for people in a regular situation; that is to say those who live legally, to find a job, what about those who are there illegally?

Akobi (Cobby) cannot work and it is this situation that Gitte, his German wife, refers to when she says that she has known Akobi as a lazy person. As a matter of fact, when Akobi has met Gitte he has begun visiting her regularly as idle as he has been. Two months later he has joined her in her one-room apartment. Six months later they have got married. Just a while after their marriage, Akobi has got a job, so he has spent more than eight months in West Germany without any job. Akobi marries Gitte not because he loves her but because it is a way out for him to get a resident card to live in the country. She is rather ugly but a very kind and lovely person. The narrator says that Gitte is "a shy, fat, young girl who was very aware she wasn't pretty. And who at nineteen had still not been kissed by a man. He gave her her first kiss and she fell madly in love with him.” (Darko, Ibid, 136:)

Akobi has succeeded in bypassing the white man's law about immigration by marrying a woman whom he does not love but since this enables him to have a resident card, he does it. It is a failure for the white man who always thinks that he is cleverer than everybody. Osey explains this to Mara before she goes and stays with the official and legal couple of Akobi and Gitte. At the same time, Akobi has his legal wife, Mara and his mistress Comfort whom Mara describes as being “Tall. Brown. Big, beautiful eyes. Sophisticated. And if she hasn't cut her hair, then plenty hair" (Darko, 1995). Instead of the only one wife Akobi is entitled to marry in West Germany, he has had three, three wives, or a wife plus two regular mistresses and in the same town, Hamburg. This is to ironize the white man who thinks that the regulation on paper must necessarily be followed by people. After his bogus marriage with Gitte his life has changed positively. But his wickedness toward Gitte and Mara on the one hand and his greed on the other, leads him to prison. Akobi has failed in Europe contrary to what he has planned because he has worked against his own plan. Akobi has failed.

Osey also has had the same experience as Akobi by marrying a German woman namely Ingrid just to have his resident card. At the same time, he has brought his African wife, Vivian to West Germany and made love with her whenever and wherever he likes (Darko, 1995). He is even jealous of her. Vivian herself tells Mara that Osey has made all the arrangement for her coming to West Germany (Darko, 1995).

Osey's misfortune is not different from Akobi's. He is greedy by involving his wife Vivian into whoring and enjoying the money by pocketing it. He even goes as far as controlling what the lady must send to her mother in Africa (Darko, 1995). He has pushed his greed too far by enjoying part of the money generated by Mara's whoring. Osey is henceforth deprived of his main source of revenue. At the same moment, his German woman Ingrid is pregnant. In a word, Osey sees himself in a life of contrast where his means decrease while the needs increase. He starts a downfall to hell. It is a failure because he has never thought of such a new deal, the new deal he must experience after Vivian's "abandoning him" is heavy and difficult to manage for him. It is a failure, Osey's one.

Apart from these two African men namely Akobi and Osey, there are other Africans who have also bypassed European laws and regulations about immigration. Here, it is African women who have taken the same way as their African brothers. They are Kaye, Vivian and Mara.

\subsubsection{Staying in Europe for Illegal Female Africans}

Vivian has been in West Germany before Mara. When the latter arrives, she is hosted in a room where Vivian lives for four days. The one-room apartment in which she has stayed with Vivian is rented from a student on vacation somewhere else with his African girlfriend (Darko, 1995). Vivian lives there as Osey's African wife but her 
occupation is whoring. She whores for two main reasons. The first one is to enable Osey to recover the money he has spent to bring her to Germany and then save enough money to pay a German man to accept a bogus (false) marriage with her with the perspective to have a resident paper (Darko, 1995). Fortunately for her, her dream comes true (Darko, 1995). She leaves Osey, engages with an American soldier but continues whoring (Darko, 1995). After her bogus marriage which entitles her a resident card, Vivian has become strong enough, self-confident and fed up with Osey's domination, she has butted him "deep in the arse". She "then kicked Osey in the arse" (Darko, 1995). She is engaged with an American soldier, Marvin.

Almost like Vivian, Mara has come and stayed in West Germany clandestinely. In her clandestineness, she has done the two jobs an African woman in such a situation can do: being either a housemaid or a whore. She has whored for Akobi for more than a year before freeing herself from Akobi's yoke (Darko, 1995). After this, she has whored in her own account and after saving enough money, she pays for a bogus marriage and therefore has her marriage certificate with the direct consequence of getting her resident card (Darko, 1995)

Kaye has experienced almost the same life of a clandestine resident in West Germany as Mara and Vivian. As a matter of fact, she has been brought to this country by her African boyfriend who has eventually maltreated her. Eventually, Kaye has a good financial position because first she is taken care of by Pompey her husband, then she is rewarded for the running of Peepy, her husband's sex club.

\section{CONCLUSION}

As a whole, both Africans and Europeans have failed but some (a few) Africans do well and colonization has shown some advantages. The white man has failed in his civilizing mission in Africa both during colonization and after. Colonization has yielded corrupt people with all its consequences on both individuals and countries. Indeed, white collars are mostly lazy people as shown in No Longer At Ease through the behaviour of some civil servants missing work just to attend Obi's trial. In the same novel, this is evidenced that people regularly go on leave and others take leave for three months. In The Beautyful Ones Are Not Yet Born, some civil servants come to office late and others enjoy leaves, arbitrarily, for several months. This state of affairs cannot generate development. That is the reason why African countries are still underdeveloped.

During colonization, human rights were not respected. As a matter of fact, the six leaders of Umuofia that the District Commissioner has imprisoned have been tortured and starved for several days by the white man's messengers and interpreters. Nowadays, corruption has been established and has become rampant in Africa. In this period, some zealous African converts have not succeeded in grasping the real scope of the Gospel. Indeed, Enoch, a new convert, has unmasked an egwugrwu and killed another one, which is against the pacific cohabitation and tolerance taught and recommended to them by Mr Brown, the white missionary, and his interpreter, Mr Kiaga for "compromise and accommodation".

All these social plagues still prevail in post-independence Africa. It is true that the white man's main objective was not to bring 'light' to Africa but to solve the economic and social difficulties he was confronted with in his own country. But he could not reach this goal without changing or helping to change Africa and Africans. At this level, he has failed. After independence, the situation, as a whole, has not changed as such. The implementation of the economic, political and social organisations left by the white man reveals to be a failure. This state of affairs is illustrated by the underdevelopment the black continent is drowned into with some political failures such as military coups and rigged (faked) democracies which are neither imported European political systems nor African ones nor a good mixture of the two. In the fields of education, administration and health, the situation is not good either, breeding thus underdevelopment.

Funding: This study received no specific financial support.

Competing Interests: The author declares that there are no conflicts of interests regarding the publication of this paper. 


\section{REFERENCES}

Achebe, C., 1975. A man of the people. London: Heinemann.

Achebe, C., 1980. No longer at ease. Heinemann: London, Ibadan.

Achebe, C., 1984. Things fall apart. London: Heinemann.

Achebe, C., 1988. The writer and his community. Hopes and Impediments: 47-61.

Armah, A.K., 1988. The beautyful ones are not yet born. Ibadan: Heinemann.

Darko, A., 1995. Beyond the horizon. 1st Edn., London: Heinemann.

\section{CONSULTED DOCUMENTS}

1-Abrahams, M, H, 2005. A glosary of literary terms. Boston: Thomson Wadsworth.

2-Ashcroft, B, et al, 2007. Post-colonial studies: the key concepts, second Edn, London and New York.

3- Barkindo, B, et al, 2014. Africa and the wider world: west and north Africa since 1800 tomes 1, 2 \&3. learn Africa Plc. Ikeja, lagos.

4-Cheikh, A, D, 1987. L’Afrique noire précoloniale. Paris. Présence Africaine.

5- Martin, M, P, and O’Meara, P, (eds). 1995. Africa, 3ird Edn. Indiana University Press. Bloomington and Indianapolis; James Currey. London.

6- Olaniyan, T and Quayson, A, 2013. African literature: an anthology of criticism and theory. Blackwell Publishing Ltd. Malden, Oxford, Carlton, Victoria.

7- Djoleto, A, 1975. Money galore. London : Heinemann

8- Dossou-Yovo, N, 1997. Individu et société dans le roman négro-africain d'expression anglaise de 1939 à 1986. Paris: l'Harmattan.

10- Klages, M, 2018. Key terms in literary theory. London, New Dehli, New York, Sydney.

11- Kounnou, A, J, 2013. Political Chaos and Corruption as the Major Causes of Africa's Underdevelopment Through Achebe's A Man of the People and Soyinka's The Interpreters, (unpublished Maîtrise thesis), University of Abomey-Calavi, Benin Republic

12-Ngugi wa Thiong'O, 1977. Weep not, child. London: Heinemenn.

13-Ngugi wa Thiong'O, 1981. The river between, London: Heinemenn.

14- Ngugi wa Thiong'O 1966. A grain of wheat, London: Heinemann.

15-Ngugi wa Thiong'o, 1986. Decolonising the mind: the politics of language in African literature. London: James Currey.

16- Ngugi wa Thiong'O, 1981. Writers in politics, London: Heinemann.

17- Ogundimu, A, S, 2008. A silly season. Lagos/Abeokuta. Campus Publications Ltd

Views and opinions expressed in this article are the views and opinions of the author(s), International Journal of Social and Administrative Sciences shall not be responsible or answerable for any loss, damage or liability etc. caused in relation to/arising out of the use of the content. 